\title{
Editorial
}

\section{Priam's Daughter: 30 years of The Geneva Papers}

\author{
The Geneva Papers (2005) 30, 1-3. doi:10.1057/palgrave.gpp.2510023
}

As students of history know, the most famous of Priam's daughters was certainly Cassandra. According to the legend, she foresaw the fall of Troy and tried to warn her fellow countrymen of this impending disaster. Alas, her message was ignored and she was caught in the catastrophe along with everybody else. Why do I use this unfortunate comparison in the title of this anniversary editorial? Because it holds several important messages:

1. To foresee the future helps little, if nobody takes notice.

2. To know the dangers helps little, if nothing is done about them.

3. To be right serves little after losing everything.

The work of The Geneva Association is certainly not the work of a fortune-teller. And still, we share the same desire of being able to anticipate the future. As the world's leading private insurance research institute, we engage in strategic research and seek to clarify the key role that insurance plays in the development of the modern economy. The Geneva Association's main goal is to study the growing importance of worldwide insurance activities in all sectors of the economy. We try to identify fundamental trends and strategic issues where insurance plays a substantial role, or which influence the insurance sector. In parallel, we develop and encourage various initiatives concerning the evolution - in economic and cultural terms - of risk management and the notion of uncertainty in the modern economy. The Geneva Association organizes global networks for experts in various fields linked to insurance: risk management, pension provision, health, regulation, and so on. It is not only an organization of and for our Chief Executive Officers (limited by the statutes to 80) of the world's most important companies, who support our work in their personal capacity. We also manage several extra-company networks of specialists from our members' companies: Chief Risk Officers; Chief Economists and Strategists; Chief Communication Officers; the Accountancy Task Force with CFOs and Chief Accountants; and the Liability Regimes Planning Board with Chief Legal Officers and General Counsels.

The Geneva Association is furthermore the publisher of leading insurance journals, newsletters and books and monographs: The Geneva Papers on Risk and Insurance Issues and Practice (four per year), The Geneva Papers on Risk and Insurance Theory ${ }^{1}$ (two per year), internal working paper series "Etudes et Dossiers" (10-15 per year), and seven different Geneva Association Information Newsletters on: Risk Management, Insurance Economics, Regulation and Trade Issues, Social Security, Health and Ageing, World Fire Statistics, and General Information, usually published twice per year. Recent books include Strategic Issues in Insurance (in 2001), September

\footnotetext{
${ }^{1}$ As of January 2005, this publication will be renamed "The Geneva Risk and Insurance Review" while keeping all its other characteristics that have made it such an important reference in the academic field.
} 
11 - One Year After: Impact, Lessons and Unresolved Issues (in 2002), Ventures in Insurance Economics - 30 Years The Geneva Association (in 2003), and Work Beyond 60 (2005, forthcoming). ${ }^{2}$

Throughout the year, The Geneva Association organizes or supports about a dozen conferences and seminars on topics that are of high relevance to the insurance industry, gathering experts from all sectors and backgrounds to combine their knowledge. The events are topics- and issues-oriented and aim at developing new knowledge and insights as well as providing platforms for expert opinion interchange. The Geneva Association is using additional means of stimulating and sponsoring research work in risk management and insurance-related fields through the availability of research grants, scholarships, prizes, and support for publishing.

The aim of the above activities is always the same: much as Cassandra wanted to know the future of her city and its inhabitants, we want to identify the strategic challenges to our societies and to the insurance industry, develop the understanding and knowledge about them, and discuss the available options and opportunities that might lie ahead. This is a task that does not only benefit the insurance industry but our economic system as a whole. Insurance and risk management play such an important role in the everyday lives of citizens on this planet. They become the bedrock of modern developed societies and are the key mechanism available to cope with future uncertainties, so this is an important exercise. We better not get it wrong.

In this process, The Geneva Papers, founded in 1975 by Raymond Barre ${ }^{3}$ and Orio Giarini, ${ }^{4}$ play a key role, being read by academics and professionals alike. They are not only our flagship publication and as such carry the central messages around the world in some of the best and most stimulating contributions published on insurance and risk management. The Geneva Papers also have the function of raising the attention for previously less visible developments and phenomena, helping to define the list of future priorities.

During these 30 years, contributions to The Geneva Papers have covered many areas. There have been special issues devoted to risk management, insurance strategy, regulation and supervision, insurability, natural and man-made catastrophes, insurance economics and finance, financial stability, bankassurance, terrorism, social security, life insurance, health and ageing, medical technology, distribution and marketing, regional challenges, and many more. One would probably be hard pressed to identify an area of relevance to insurance that was not covered by a contribution to The Geneva Papers. In a sense, The Geneva Papers have been a mirror and companion of the general development of insurance and risk management. To provide some figures: a total of 870 articles (not counting numerous editorials) in 113 issues were published in the past three decades, covering more than 13,000 pages. Over 600 authors contributed to the journal and more than 200 persons from all six continents

\footnotetext{
${ }^{2}$ For more information on these books, please contact the General Secretariat of The Geneva Association via emailinfo@genevaassociation.org or visit our website www.genevaassociation.org

${ }^{3}$ At the time, President of The Geneva Association and later Prime Minister of France.

${ }^{4}$ The first Secretary General of The Geneva Association and first Editor-in-Chief of The Geneva Papers.
} 
were involved in the editorial work, either as Members of the Editorial Board or during the review process.

To revert back to Priam's famous daughter:

1. We want to anticipate the future and make the insurance industry, experts and policymakers take notice.

2. We want to know the dangers ahead and support proactive action by doing something about them.

3. We want to be scientifically correct and verifiable so as to avoid potential catastrophes.

The Geneva Papers on Risk and Insurance - Issues and Practice are an established journal with a very specific aim. They have been able to keep the edge and proven their value over the past 30 years. This has only been possible due to the goodwill and support this publication has received from so many sides. We would like to thank everybody - and the list is long - who has been involved in the venture of discovering and treating insurance and risk management issues.

Patrick M. Liedtke

Secretary General and Managing Director of The Geneva Association and Editor-in-Chief of The Geneva Papers on Risk and Insurance - Issues and Practices 